\title{
Small Intestinal Adenocarcinoma
}

National Cancer Institute

\section{Source}

National Cancer Institute. Small Intestinal Adenocarcinoma. NCI Thesaurus. Code C7888.

An adenocarcinoma that arises from the small intestine. Histologic variants include mucinous adenocarcinoma and signet ring cell carcinoma. 